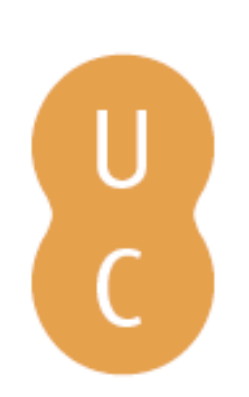

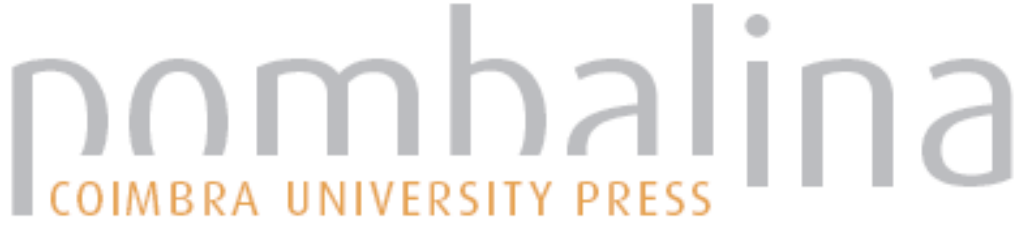

\section{More thoughts on open texture in athenian law}

\author{
Autor(es): Harris, Edward M. \\ Publicado por: Imprensa da Universidade de Coimbra \\ URL \\ persistente: URI:http://hdl.handle.net/10316.2/34654 \\ DOI: $\quad$ DOI:http://dx.doi.org/10.14195/978-989-26-0903-4_15
}

Accessed : $\quad$ 26-Apr-2023 10:26:27

A navegação consulta e descarregamento dos títulos inseridos nas Bibliotecas Digitais UC Digitalis, UC Pombalina e UC Impactum, pressupõem a aceitação plena e sem reservas dos Termos e Condições de Uso destas Bibliotecas Digitais, disponíveis em https://digitalis.uc.pt/pt-pt/termos.

Conforme exposto nos referidos Termos e Condições de Uso, o descarregamento de títulos de acesso restrito requer uma licença válida de autorização devendo o utilizador aceder ao(s) documento(s) a partir de um endereço de IP da instituição detentora da supramencionada licença.

Ao utilizador é apenas permitido o descarregamento para uso pessoal, pelo que o emprego do(s) título(s) descarregado(s) para outro fim, designadamente comercial, carece de autorização do respetivo autor ou editor da obra.

Na medida em que todas as obras da UC Digitalis se encontram protegidas pelo Código do Direito de Autor e Direitos Conexos e demais legislação aplicável, toda a cópia, parcial ou total, deste documento, nos casos em que é legalmente admitida, deverá conter ou fazer-se acompanhar por este aviso.

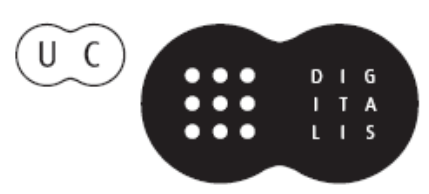




\section{Delfim F. Leão - Livio Rossetti Maria do Céu G. Z. Fialho (eds.)}
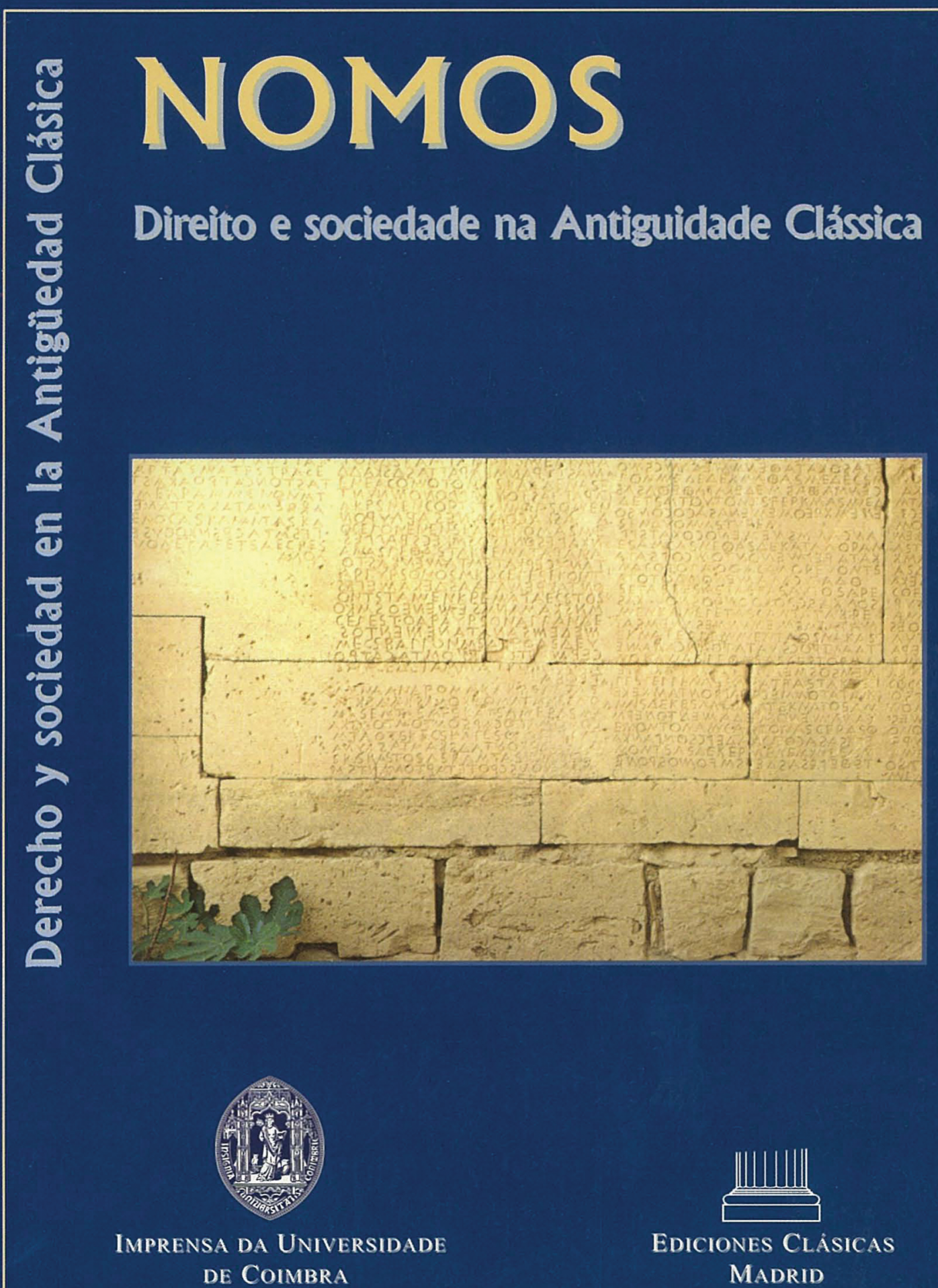

Ediciones Clásicas MADRID 


\title{
MORE THOUGHTS ON OPEN TEXTURE IN ATHENIAN LAW
}

\author{
Edward M. HARRIS
}

\begin{abstract}
In his The Concept of Law Hart observes that laws are usually general rules that deal with broad categories of actions or individuals. When applying a law to a particular case, however, it is sometimes unclear whether a certain action or individual belongs in the category which the law covers. Legislators often try to formulate detailed definitions of key terms to resolve these problems, but it is impossible to remove entirely law's "open texture".

Modern scholars of Athenian Law have paid little attention to law's open texture. On the one hand, formalist scholars like H. J. Wolff and H. Meyer-Laurin have assumed that Athenian laws were so clear and simple that they posed no problems of interpretation. On the other, those scholars who believe that the Athenian courts were mainly an arena for aristocratic competition think that Athenian law was mainly concerned with procedure. As a result, litigants paid little attention to the substantive issues raised by law's open texture. This essay will show that litigants were aware of the open texture of Athenian law and often based their arguments on an interpretation of statute. The essay will also show that the Athenian courts tended to side with the litigant who based his case on customary or most straightforward reading of a statute and tended to reject cases that relied on new or unusual readings of the law.
\end{abstract}

In his The Concept of Law H. L. A. Hart observes that the law must refer to broad classes of persons or classes of acts, things, or circumstances. The operation of the law therefore depends on the «capacity to recognize particular acts, things and circumstances as instances of the general classification which the law makes» ${ }^{1}$. In most cases, this is not a difficult process. From time to time, however, one encounters «fact-situations (...) which possess only some of the features of the plain cases but others which they lack» ${ }^{2}$. One might try to avoid this problem by formulating detailed definitions of key terms that would clarify how they were to be applied in

\footnotetext{
${ }^{1}$ HART (1961) 121.

${ }^{2}$ HART (1961) 123.
} 
any given situation. Yet, as Hart rightly notes, it is impossible to find a rule «so detailed that the question whether it applied or not to a particular case was always settled in advance and never involved, at the point of actual application, a fresh choice between open alternatives ${ }^{3}$. The legislator simply cannot know in advance all the different kinds of situations that will occur in the future ('ignorance of fact'). One might attempt to eliminate the problem by formulating canons of interpretation. As Hart observes, however, this approach would lead to similar problems because such canons would likewise be general rules, which one would also have to apply to particular cases of interpretation ${ }^{4}$.

In hard cases, where it is not clear how to apply the general rule to a specific situation, Hart believes «all that the person called upon to answer can do is to consider (as does one who makes use of a precedent) whether the present case resembles the plain case 'sufficiently' in 'relevant' respects. $\rangle^{5}$ One extreme approach to the issue of the 'open texture' of the law is formalism, which «seeks to disguise and to minimize the need for such choice once the general rule has been laid down.» In this 'heaven of concepts' a rule has the same meaning in all situations. The other extreme is an approach that regards all rules as «perennially open or revisable.» Hart criticizes this approach because it pays «too little respect to such limits as legislative language, despite its open texture, does after all provide.» In his opinion, most legal systems tend to compromise between two needs - first, there is the need for clear rules that everyone can apply to his or her conduct, and second, the recognition that there will arise disputes about the law that only an individual can resol$\mathrm{ve}^{6}$.

Hart's analysis of 'open texture' is perceptive, but his main observation is not entirely original. The view that the law must provide general rules goes back to Plato and Aristotle. In the Statesman (295a) Plato observes that a legislator who «has to give orders to whole communities of human beings in matters of justice and mutual contractual obligation will never be able in the laws he prescribes for the whole group to give every individual his due with absolute accuracy.» Instead the legislator will make «the law for the generality of his subjects under average circumstances. Thus he will legislate for all individual citizens, but it will be by what may be called a 'bulk' method rather than an individual treatment (...).» Aristotle (Politics, 1292a33) also noted that the laws should deal with all general matters, but that magistrates would deal with particular circumstances. This was necessary because of the «because of the difficulty of making a general rule to cover all cases» (Politics, 1282b2). In particular, Aristotle or one of his students (Ath. Pol. 9.2) noted that the laws of Athens were often unclear, leaving the power of decision for

\footnotetext{
${ }^{3}$ HART (1961) 125.

${ }^{4}$ HART (1961) 123.

${ }^{5}$ HART (1961) 123.

${ }^{6}$ HART (1961) 126-7.
} 
any given case in the hands of the court. Some argued that the lawgiver Solon did this deliberately so as to unfetter the judges' power of the judges to decide cases. But Aristotle rightly dismisses this view and argues that the alleged lack of clarity results from the difficulty of «defining what is best in general terms.»

Aware of the 'open texture' of law, Aristotle (Rhetoric, 1.13.1373b-74a) realized that one of the crucial tasks facing a litigant was to define clearly the nature of the wrongdoing his case involved:

Since people often admit having done an action and yet do not admit to the specific terms of the an indictment or the crime with which it deals - for example, they confess to having 'taken' something but not to have 'stolen' it or to have struck the first blow but not to have committed hybris or to have stolen something but not to have committed 'sacrilege' ([claiming] what they took from a temple did not belong to the god) or to have trespassed but not on state property or to have had conversations with the enemy but not to have committed treason - for this reason [in speaking, we] should give definitions of these things: what is theft? what is hybris (outrage)? what is moicheia (seduction)? In so doing, if we wish to show that some legal term applies or does not, we will be able to make clear what is a just verdict.

In this essay I will explore how litigants in Athenian courts approached the problem of open texture. Even though litigants usually do not explicitly state that they are adopting a particular definition of a key term in a statute, a careful analysis of the arguments in several orations show that they were implicitly aware of the problem of open texture. In an earlier essay, I criticized the two main approaches that have recently dominated the study of Athenian legal system for not paying enough attention to the problem of open texture in Athenian law ${ }^{7}$. On the one hand, several scholars such as H.-J. Wolff, H. Meyer-Laurin, and Meinecke, who take a formalist approach to Athenian law, rightly stress the importance of the judicial oath, which bound judges to decide cases in accordance with the laws and decrees of the Athenian people ${ }^{8}$. These scholars believe, however, that these rules gave judges clear guidance about how to resolve disputes and decide cases. Meinecke in particular points to Demosthenes' list of requirements for the correct kind of law, which includes the need to be «written in terms that are simple and easy for all to understand, not in a way so that it is possible for one man to think it says this, another that» $(24.68)^{9}$. This view has much to recommend it, but it tends to underestimate the amount of 'open texture' contained in Athenian laws. Demosthenes' requirements for the right kind of law is the description of an ideal; there is no need to assume that the actual laws of Athens always lived up to this ideal. Indeed, the author of the

\footnotetext{
${ }^{7}$ Harris (2000a).

${ }^{8}$ Wolff (1963) 87ff.; Meyer-Laurin (1965); Meinecke (1971). Cf. Wolf (1956) 167, $343 \mathrm{ff}$, $361 \mathrm{ff}$.

${ }^{9}$ MeINECKE (1971) 354-5. For the view that Athenian laws provided clear and straightforward guidelines see also Aeschines 3.199 and Lycurgus Leocr. 9.
} 
Constitution of the Athenians (9.2) noted that the laws of Solon were often not simply nor clearly written, a situation that gave rise to many disputes, which the court had to decide. And Aristotle (Rhetoric, 1373b-74a) would not have advised potential litigants to pay careful attention to the definition of key terms if the meaning of all terms in every statute was always clear and unambiguous.

On the other hand, those scholars like D. Cohen and J. Ober, who view the Athenian courts primarily as arenas for social and political conflict, pay little attention to the implications of the judicial oath. Since these scholars believe that Athenian law aimed mainly to provide a set of procedural mechanisms for getting a case into court, they pay less attention to substantive issues, where the problem of open texture arises. ${ }^{10}$ To support their argument, these scholars often point to the absence of definitions for key terms in Athenian statutes ${ }^{11}$. If the Athenians were really interested in substantive issues, they would have surely have provided definitions. In their view, trials at Athens were agones where litigants, mostly wealthy, competed for prestige in front of hundreds of citizens. Advocates of this approach claim that men who spoke in Athenian courts did not concentrate primarily on the issues of fact and law raised by the legal plaint, but often appealed to political considerations or took advantage of their social prestige ${ }^{12}$. Christ has gone so far as to claim that litigants paid little attention to the letter of the law ${ }^{13}$.

There are several general objections to bring against this portrait (one is tempted to say caricature) of the Athenian legal system ${ }^{14}$. The oath that judges were required to swear bound them to vote according to the laws and decrees of the Athenian people and to disregard irrelevant material. Not only did they swear this way, but litigants constantly reminded them of their duty to follow the law and clearly expected them to comply ${ }^{15}$. That is not to say that the Athenian courts always lived up to this ideal. But we should not dismiss the oath as mere propaganda. Nor should the absence of definitions in a statute be taken as evidence that a legal system is not interested in substantive matters or does not consider substantive issues when deciding disputes ${ }^{16}$. For instance, the laws of the United States do not provide a definition of the term "executive privilege". Yet no one would argue that the Supreme

${ }^{10}$ For this view see, for example, HANSEN (1975) 10; TodD (1993); COHEN (1995) 190. CAREY (1998) rightly questions the traditional assumption that "Athenian law was primarily procedural in its orientation".

${ }^{11}$ For example, TodD (1993) 65-67.

${ }^{12}$ The traditional assumption that Athenian litigants did not "stick to the point" is incisively questioned in a forthcoming essay by P. J. RHODES.

${ }^{13}$ Christ (1998) 193-224. For a critique of Christ's assumptions see HARris (2000b).

${ }^{14}$ For a detailed critique of Cohen's attempt to interpret Athenian litigation in terms of feuding behavior see HARRIS (forthcoming).

${ }^{15}$ For allusions to the judicial oath see HARRIS (1994) 149, notes 6 and 7.

${ }^{16}$ On the problem of definitions in modern law, see KATZ (1987) 88-96. On the absence of definitions in Athenian Law and its implications, see HARRIS (1988) 367-70. 
Court did not consider the substantive issue of whether or not President Nixon had a right to refuse to hand over tapes relating to the Watergate scandal on the grounds of "executive privilege." Likewise in Athens, we will find that even in cases where the law does not provide a definition or other explanation, the litigants sometimes base their case on interpretation of statute. When they argue for an interpretation of the law, they pay careful attention to the wording of the law.

In my earlier essay, I examined the legal arguments in several cases to study how Athenian litigants dealt with the problems posed by the open texture of law ${ }^{17}$. I also looked at the known verdicts in these cases to see how Athenian magistrates and Athenian courts dealt with cases where litigants attempted to stretch the application of a given law beyond its normal limits. My aim was in part to construct a via media between the formalist approach of $\mathrm{H}$. J. Wolff and Meyer-Laurin (to which I am sympathetic) and the political and sociological approach of recent English and American scholars ${ }^{18}$. My general conclusion was that while magistrates gave accusers considerable latitude when it came to accepting cases, the courts were generally reluctant to vote for accusers who relied on new or unusual interpretations of statutes.

In this essay, I will analyze the legal arguments in several more cases to bring additional support to the conclusions reached in my earlier essay. First, I will examine three cases where there was a potential ambiguity about the meaning of the language in a statute or a contract. In these cases we will find that each litigant followed a different interpretation of a key term or phrase, one that naturally tended to favor his position and undermine that of his opponent. Second, I will study cases where one of the litigants appears to have relied on a new or unusual reading of the language found in a contract or law. Here we will find that the court which judged these cases sided with the other litigant, who relied on a more straightforward interpretation of legal terms.

Athenian law contained three basic categories of homicide (Ath. Pol. 57.3): phonos ek pronoias, which was tried at the Areopagos, phonos akousios ("unwilling homicide") tried at the Palladion, and phonos dikaios or kata tous nomous ("just homicide" or "homicide in accordance with the laws") at the Delphinion. The Palladion also tried cases of "plotting homicide (bouleusis phonou)," which was

\footnotetext{
${ }^{17}$ HARris (2000a).

${ }^{18}$ My approach is close to that of BISCARDI (1999) 90: «Pour ma part, je me propose de démontrer que peut-être la vérité se trouve à mi-chemin». Cf. Hillgruber (1988) 119: «Die Athener sind offentsichlich bei der Lösung juristischer Probleme sehr flexibel gewesen, da sie sich an kein juristisches Prinzip der Billigkeit - insofern die Hauptthese von Meyer-Laurin zutreffend - noch an ein starres Gesetzprinzip».
} 
roughly equivalent to attempted homicide ${ }^{19}$. The range of the first kind of homicide has been the subject of disagreement among scholars. Several writers translate the term ek pronoias as "premeditated homicide" or "with malice aforethought", while others translate it as "intentional homicide" 20 . The best way to resolve this debate over the meaning of the term is to examine the passages in Greek prose where the phrase occurs and find which meaning fits best in each context. What one should not do is to assume that the Athenian category is equivalent to a category in a modern lawcode or determine the meaning of ek pronoias on the basis of a superficial linguistic similarity ${ }^{21}$.

The word pronoia is found in over 150 passages in the surviving literature of the fifth and fourth centuries B.C. The word is normally used in the sense of foresight, that is, the ability to see the future consequences of present actions. For instance, Thucydides (2.65.6) speaks of Pericles' ability to foresee what would happen during the war with Sparta. Or to take another example, when he was struck by Meidias, Demosthenes (21.76) says that he used so much pronoia about causing irreparable damage that he did not strike back. Here the noun does not refer to any planning or prior intent on Demosthenes' part since he had no way of knowing that Meidias would strike him in the theater at the Dionysia. He acted with pronoia because he considered the potential consequences of a violent reaction in the future. His pronoia concerned the irreparable damage that might have occurred as a result of striking back. The word pronoia is thus unlike the noun boule, which refers to a plan formed in the past, that is, before one acts. When one acts with pronoia, by contrast, one looks into the future and considers what will happen after one acts. Thus when writers say that a person "has pronoia" or "had pronoia", this person acted in a way that showed he was aware of the possible results of his actions. When Aristocrates drew up his decree for Charidemus, he had pronoia that it would remain in force and not be repealed or changed in the future (Demosthenes 23.62) ${ }^{22}$. An action done with pronoia is not planned in advance and contrasted with a spontaneous action; on the contrary, it is an action done on purpose as opposed to one that happens "by chance" (Antiphon 5.6, Xen. Hell. 7.5.8; Herodotus 3.121).

The expression ek pronoias is relatively rare. It is found in fewer than twenty passages, only a handful of which indicate the circumstances of the action in enough detail to help determine its meaning. Perhaps the best passage comes from

\footnotetext{
${ }^{19}$ On attempted homicide in Athenian law see HARRIS (2001).

${ }^{20}$ CARAwan (1998) 235-8 translates the term "with malice aforethought"; STRoud (1968) and WALLACE (1989) 125 translate the term as "premeditated homicide", while MACDowell (1963) translates it as "intentional homicide".

${ }^{21}$ For instance LoOMIs (1972) assumes that phonos ek pronoias is premeditated homicide, but then after a study of several passages about trials for murder discovers that this translation does not fit the context. He would have done better to begin without making any assumption about the meaning of the term.

${ }^{22}$ Compare Demosthenes 20.88 where we find the phrase "we have pronoia" followed by a hopos clause containing verbs in the future tense.
} 
Herodotus' story about Artemisia at the battle of Salamis told by Herodotus (8.87.23). During the battle Artemisia's ship was being pursued by an Athenian trireme and was unable to get away since its path of escape was blocked by a friendly ship. Instead of stopping or attempting to change course, Artemisia rammed the friendly ship. Xerxes, who was observing the battle from afar, thought she rammed a Greek ship and praised her for her valor. Herodotus adds that it is uncertain whether Artemisia did hit the other trireme ek pronoias or happened to collide "by chance". The contrast is between an action undertaken on purpose and one that is a product of happenstance, not between planned and unplanned action. There can be no question of premeditation since Artemisia found herself in an unexpected predicament and acted on the spur of the moment.

Another passage in Herodotus (1.159) points in the same direction. Aristodicus had received Pactyes as a suppliant when he had fled from the Persians. When the Persians demand his surrender, Aristodicus went to Branchidai to consult the god there about what to do. To his astonishment, the god instructed him to surrender Pactyes. Aristodicus then went around the temple removing all the swallows and other birds nesting there. At this point the gods indignantly asked why he was removing his suppliants. Aristodicus replied by pointing out the god's hypocrisy: how could the god object to Pactyes removing suppliants when he commanded Aristodicus to surrender Pactyes? Once more ek pronoias must mean "on purpose". The act of removing the birds is not planned ahead of time - Aristodicus clearly did not expect to receive the initial response from the god - but undertaken after he receives an unexpected answer to his inquiry. Note that an action taken ek pronoias looks forward to another action taken in the future. The removal of the birds is done for the purpose of eliciting the god's objection so he can point out his hypocrisy ${ }^{23}$.

In a passage from Aeschines (3.178) there is a different kind of contrast, this time between ek pronoias and ex ethous - "from custom" or "by habit". Aeschines is discussing how Athenians in the past were sparing about conferring honors; they. thought that a reputation for virtue in and of itself used to be considered sufficient. In the degenerate present, however, the Athenians confer honors "as a matter of habit, but not deliberately". An action done with thought is contrasted with one done without thinking about the consequences.

This examination of passages where the term is used shows that phonos ek pronoias must be "intentional homicide" or "homicide committed on purpose". The

${ }^{23}$ The expression is used in a similar way at Aristophanes Eq. 848-57. In this passage the SausageSeller accuses the Paphlagonian slave - a thinly disguised Cleon - of plotting against the Athenian people. He draws attention to the shields captured a Pylos which Cleon had given as a dedication. The Sausage-Seller observes that the handles were left on the shields when they were dedicated and triumphantly declares that this was done ek pronoias - on purpose. If Cleon is ever ostracized, the SausageSeller says that Cleon's cronies will arm themselves with these shields and stage a coup d'état to prevent his banishment. The act of leaving the handles on the shields is done with a purpose - looking forward to a future action - enabling Cleon's cronies to start a revolution. 
question arises "what kind of intention?" Did the accuser have to prove that the defendant intended to kill his victim or merely that the action which brought about the death of the victim was intentional? The decisions reported in two actual cases seem to point in different directions. Aristotle (Magna Moralia, 1188b30-37) reports: «They say that a woman gave a potion to someone to drink, and then the man died from the potion, and the woman was put on trial on the Areopagus. When she appeared there, they acquitted her for no other reason than because (she did) not (do it) intentionally. For she gave it out of love but she failed to achieve her goal. For this reason it did not seem to be willing since she gave it a potion and not with the intention that the man die.» The significant point about the decision of the Areopagos is that these judges appear to have interpreted the term phonos ek pronoias to mean "with the intention that the victim die" as a result of the defendant's action $^{24}$. In other words, the Areopagos required the accuser to show that the defendant intended not just to harm, but to kill the victim. In this case, the defendant (or the person who spoke for her) convinced the court that her intention was to make the victim fall in love (or stay in love) with her and not to kill him. Though one might have argued that giving a love potion was an attempt to harm, the Areopagos found her innocent since she did not intend to kill her victim.

Another case points in a different direction. In his speech Against Meidias, Demosthenes (21.71-76) recounts the murder of a man named Boeotus by an acquaintance called Euaion ${ }^{25}$. Both men were at a party attended by several friends, when Boeotus became drunk and hit Euaion in an insulting way. Euaion felt humiliated and immediately struck back with such violence that he killed Boeotus. The case must have come before the Areopagos because the relatives of the victim could charge Euaion with causing death by a deliberate blow. Besides, the case does not fit any of the categories listed under the rubric "just homicide" or "homicide according to the laws." ${ }^{26}$ Demosthenes (21.75) says that the court voted narrowly to convict Euaion and infers the reason for their decision. In his opinion, the majority who voted against Euaion considered that he had struck back in such a way as to cause the death of his victim. The court decided to convict him even though it was clear that he was only attempting to retaliate for the humiliation he had suffered. The court did not expect the accuser to prove that Euaion intended to kill his victim. It was enough for him to show only that Euaion wanted to hurt Boeotus, which was beyond question. Euaion had struck back intentionally, and his deliberate action had caused death: that was enough to merit conviction.

\footnotetext{
${ }^{24}$ Note that Aristotle glosses the phrase $e k$ pronoias with the word dianoia with a future infinitive.

${ }^{25}$ MACDoweLl (1990) 292-3 believes the trial involved a case of self-defense and was tried at the Delphinion, but Demosthenes' narrative does not indicate that Euaion had to use deadly force to avoid serious physical harm. In fact, he says Euaion could have restrained himself and won the approval of those present. For an analysis of the case see HARRIS (1992) 78.

${ }^{26}$ For these categories see MACDowell (1963) 70-81.
} 
Needless to say, an accuser or a defendant would choose the interpretation of the term phonos ek pronoias that tended to favor his case. An accuser might have a hard time proving that a defendant actually intended to kill his victim. Even if the defendant used a weapon, it might be difficult to determine whether he meant to kill or merely to wound. By contrast, it would be much easier to demonstrate that the defendant wanted to harm the victim. All one would have to show was that the defendant had hostile intent and was acting in a way that was likely to cause harm. The defendant however would naturally want to make his opponent's task as difficult as possible and would ask the court to require that the accuser show that he aimed to kill the victim, not just harm him ${ }^{27}$.

The author of the Tetralogies attributed to Antiphon was aware of the potential ambiguity and realized that an accuser and a defendant might adopt different interpretations of the term ${ }^{28}$. The Third Tetralogy deals with a case of phonos ek pronoias that is roughly similar to the murder of Boeotus by Euaion. Just as in the case described by Demosthenes, both the victim and the defendant were attending a party. The victim got drunk and struck the defendant in an insulting way. The defendant retaliated by striking back, but hit the victim so hard that he caused serious injury. Here the case in the Third Tetralogy differs from the case recounted by Demosthenes: the victim did not die immediately but several days later after receiving treatment from a doctor (Antiphon 4.2.4). The tetralogy follows Athenian procedure in giving two speeches to the accuser and two to the defendant, but in this case the defendant voluntarily went into exile after the first pair of speeches and allowed a relative to make the second speech for him (Antiphon 4.4.1. Cf. Antiphon 5.13; Dem. 23.69).

In his first speech the accuser states that the defendant became drunk and hit and choked the victim until he died (Antiphon 4.1.6). In reply the defendant draws attention to extenuating circumstances and presents several arguments to deny his guilt (Antiphon 4.2). In his second speech to the court, the accuser notes that the defendant admits that he struck the victim with blows that caused his death (Antiphon 4.3.2) and finds it paradoxical that he claims that he has not murdered the victim. His phrasing is significant: he implies that all that it is necessary to prove is that the defendant struck deliberately and that his blows caused death. Later in his speech he makes this point explicit: «if our hands accomplish for each of us what we intend, (...) the man who struck with deadly force was responsible for the death. For the man died from actions which that man did intentionally

\footnotetext{
${ }^{27}$ Note how the defendant in a case of trauma ek pronoias claims that his accuser must prove not that he intended to wound but actually intended to kill (Lys. 3.41). The defendant claims that this is the way previous courts have interpreted and argues that otherwise those involved in brawls would be sent into exile (Lys. 3.42-3). His opponent apparently relied on the fact that he was carrying a potsherd, which indicated his intention to wound (Lys. 3.28), and may have argued that all he needed to do was to show that the defendant intended to wound.

${ }^{28}$ On the authorship of the Tetralogies, see GAGARIN (1997) 8-9 with references to earlier opinions.
} 
(Antiphon 4.3.4).» In his opinion, he does not have to prove the defendant intended to kill; it is sufficient for him to show that the act which caused death was intentional (dianoetheis).

The relative of the defendant who took up his case after he left for exile followed a different interpretation of the term. He admits that «if the man who struck the first blow intended to strike and not to kill, while the man who struck back intended to kill, the latter would have been the one who aimed to cause death» (Antiphon 4.4.4). In other words, if the accuser can prove that the defendant intended to kill, then he is guilty of phonos ek pronoias. But this is not the case: «now as it is, the man who struck back failed to achieve his aim when intending to strike and not to kill. $\rangle^{29}$ This defense is similar to the one used to secure the acquittal of the woman tried at the Areopagos for poisoning: just as she claimed to give the potion for love, not intending that the victim die, the speaker in the Third Tetralogy asserts that his relative struck with the intent only to hit the victim, not to kill him. In each case, therefore, the defendant was not guilty since there was no intent to kill. The speaker concludes that the defendant was only the party responsible for the blow (Antiphon 4.4.5). The speaker then goes a step further and claims that since the defendant was responding to a provocation, he was acting against his will (akousios) and cannot be held responsible for the results of his action. He stresses again that his motive was to avenge an injury (Antiphon 4.4.5). The death was the product of a mistake, his failure to achieve his aim of merely striking a blow, an error that occurred when he was acting under compulsion ${ }^{30}$. In the next section the speaker shifts his ground slightly but sticks to his point that the defendant did not intend to kill (Antiphon 4.4.6). Here he claims the defendant was seeking to avoid harm and to thrust the victim away. Instead of trying to kill, the defendant merely wished to escape from the assailant.

In the statutes about homicide in his Laws (865a-874e), Plato attempted to remove these ambiguities. To deal with cases of provocation such as the one in the Third Tetralogy, Plato adds two categories of homicide not found in Athenian law (Laws, 866d-867e). First, there is the case where someone acts in anger and retaliates immediately without planning ahead to kill, then feels repentence. Second, there is the man who is insulted and becomes angry, then later kills with the intent to kill and feels no remorse. The latter resembles the person who kills willingly, while the former is like the person who kills unwillingly. Plato therefore imposes a harsher penalty on the latter and a milder on the former. If a man kills a free person with his own hand, in anger, and without prior planning, he will go into exile for two

\footnotetext{
${ }^{29}$ Here and elsewhere GAGARIN (1998) 46 translates the participle amunomenos "defending himself" or "in self-defence" but the verb does not imply the agent is defending himself, but is striking back in retaliation. See for instance Thucydides 1.96.1 where the ostensible aim of the Delian League is «to retaliate for what the cities suffered by ravaging the King's land». Here the Greeks are not defending themselves but going on the offensive to avenge the damage done by the Persians.

${ }^{30}$ Compare the defense offered for the woman who gave the love potion.
} 
years. On the other hand, if a man kills in anger but kills "after planning" i.e. to kill, he will go into exile for three years ${ }^{31}$. Thus Plato distinguishes between a case where the defendant kills without intending to and a case where the the defendant aims to kill and achieves his aim. Since the latter is a more serious offense, it receives a harsher penalty.

The law of homicide furnishes another example of the open texture of Athenian law. The expression ek pronoias in the Athenian category of phonos ek pronoias contained an ambiguity, which made it possible to interpret the law in two ways. The Third Tetralogy shows how an accuser and a defendant might interpret the phrase in different ways, each one suited to the needs of his case ${ }^{32}$. This ambiguity and the potential problems it might cause did not go unremarked: in the Laws Plato created two additional categories of homicide and specified the nature of the intent required in each category as a way of removing the ambiguity and solving the problem.

The law about eisangelia dealt with major offenses against public security and made several types of offenders subject to its provisions ${ }^{33}$. One clause of the law covered those who tried to overthrow the Athenian people or who held a meeting or formed a group for that purpose (Hyp. Eux. 7-8). Another clause applied to those who betrayed a city or ships or an army or fleet (Hyp. Eux. 8). The law also made it possible to prosecute the person who «says things as a public speaker (rhetor) not in the best interests of the Athenian people and takes money for doing so.» This clause did not apply to all citizens but only to the "public speaker". The law does not define the term "public speaker", but the Athenians made a general distinction between "public speakers" (rhetores) and "private citizens" (idiotai). In general, private citizens were those who were not active in politics ${ }^{34}$. Rhetores were obviously included those who regularly spoke in the Council and Assembly and proposed decrees. But how much public speaking did one need to do to qualify as a "public speaker"? Was one speech in the Council or Assembly enough to make one a "public speaker"? Or did one have to propose a decree? And was passing one decree enough to earn one the title of "public speaker"?

In a thorough study of the term rhetor $\mathrm{M}$. H. Hansen concludes that the term rhetor had both a narrow and a broad sense ${ }^{35}$. In a more narrow sense «rhetor denotes

${ }^{31}$ In his discussion of phonos ek pronoias Plato (Laws, 869e-870d) does not mention the problem of the killer's intention, but by listing the possible motives for this kind of homicide helps to remove the issue.

${ }^{32}$ The Sophists may have played a major role in the analysis of open texture. For instance, Pheidippides, who received a sophistic education in Aristophanes' Clouds (1185-1200), claims to find an ambiguity in the law about summonses and exploits it to help his father's case.

${ }^{33}$ For the terms of the law on eisangelia see HANSEN (1976) 12-20.

${ }^{34}$ On the idiotes see RuBINSTEN (1998).

${ }^{35}$ HANSEN (1983) 39-40. 
a citizen who moves a psephisma in the ecclesia or in the boule or a nomos before the nomothetai or brings a public action before the dicasteria. In a wider sense a rhetor is a speaker addressing the ecclesia or the boule (either supporting or opposing a psephisma moved by another rhetor) or a synegoros addressing the court (either for the prosecution or the defence).» In fact, the law regulating the examination of public speakers (dokimasia rhetoron) allows for prosecution in the case where "someone speaks in the Assembly» (Aeschin. 1.28). This would appear to cover anyone who makes a speech in the Assembly, not just those who propose decrees.

The meaning of the term rhetor may seems like a trivial point, a matter of quibbling over words, but it became a matter of life or death when Polyeuctus prosecuted Euxenippus by eisangelia sometime between 330 and $324^{36}$. The main facts of the case were not in dispute. After Philip of Macedon restored the territory of Oropus to the Athenians, the land was divided up into five parcels and distributed to pairs of Attic tribes (Hyp. Eux. 16) ${ }^{37}$. There then arose a dispute about a hill given to the tribes Acamantis and Hippothontis. Before the division, fifty border commissioners had marked out the hill as the property of the god Amphiaraos (Hyp. Eux. 16). To resolve the dispute, the Assembly instructed Euxenippus and two other men to pass the night in the temple of Amphiaraos. That night Euxenippus fell asleep and had a dream, which he reported to the Assembly (Hyp. Eux. 14). Hyperides does not say what Euxenippus told the Assembly; all he says is that Polyeuctus proposed a motion to restore the land to Amphiaraos (Hyp. Eux. 16) and that the remaining eight tribes make payments to Acamantis and Hippothontis by way of compensation for their loss (Hyp. Eux. 17) ${ }^{38}$. An unknown accuser prosecuted Polyeuctus for proposing an illegal motion and won a conviction ${ }^{39}$. Polyeuctus had to pay a small fine, then brought his case against Euxenippus (Hyp. Eux. 18).

When he drew up his indictment, Polyeuctus followed the language of the statute about eisangelia: he accused Euxenippus of «speaking against the best interests of the people of Athens while taking money and gifts from those who were acting against the people of Athens» (39). By using the procedure of eisangelia, Polyeuctus had in effect placed Euxenippus in the category of rhetores (Hyp. Eux. 30). Despite Hyperides' protests, this was not unjustified since someone who had spoken in the Assembly was on the broad interpretation of the term rhetor subject to eisangelia. But Hyperides insists that the law does not apply to Euxenippus. He observes that the law only applies to those who are rhetores, then adopts the narrower definition of this term as those who propose decrees (8). On this definition,

\footnotetext{
${ }^{36}$ For the date of the speech see WHITEHEAD (2000) 155-57.

${ }^{37}$ This took place either in 338 or in 335. See Whitehead (2000) 207.

${ }^{38}$ For the various possible relationships between Euxenippus' report and the proposal of Polyeuctus see WHITEHEAD (2000) 201-3.

${ }^{39}$ There is no need to think that Euxenippus was the accuser - see WHITEHEAD (2000) 202.
} 
Euxenippus is not a rhetor, but a private citizen (idiotes), a point which Hyperides repeats several times. Polyeuctus should not prosecute private citizens (Hyp. Eux. 26); Hyperides himself has prosecuted only generals and public speakers (Hyp. Eux. 28). Although Euxenippus is a private citizen, Hyperides argues that Polyeuctus treats him as if he were a public speaker (Hyp. Eux. 30). If Euxenippus had made a false report about the god's wishes and did not propose a decree, eisangelia was the wrong procedure to use against him: one should have instead sent to Delphi to find out what the god really thought (Hyp. Eux. 15).

Hansen rightly observes the trial of Euxenippus illustrates the «clash between (...) two uses of the term rhetor». In the broad sense, rhetor «occurs in nomoi and signifies any citizen who addresses his fellow citizens in the assemblies (...).» But «in the much narrower sense» the term rhetor is «a citzen who addresses his fellowcitizens habitually, sometimes even professionally» and distinguished from «the citizen who only once or at intervals performs the part of ho boulomenos is described as an idiotes $\rangle^{40}$. Hyperides (Eux. 3, 9-10, 30) claims that the prosecutor had drawn up an illegal indictment, but the charge is plausible only if we accept his definition of the term rhetor. What is more likely is that Polyeuctus followed the broader interpretation of the term, one that was implicit in the law about the scrutiny of public speakers. Here again we find a law which contains a potentially ambiguous term, which can be interpreted in at least two ways. Not surprisingly, opposing litigants might base their arguments on varying definitions of the same term. When composing his speech, Hyperides clearly paid careful attention to the substantive provisions about the law on eisangelia. Despite Hyperides' allegations, it is likely that his opponent did the same.

In the cases examined in Section I, we do not know what verdict the court rendered. In the next two cases, however, we either know or can infer the decision made by the court.

The Athenians had three laws about real security, which protected the rights of the creditor to property he acquired as a result of a debtor's default ${ }^{41}$. One law granted full rights of ownership to the creditor who accepted some property, either movable or immovable, as security for a loan or other obligation and took possession of this property in lieu of repayment of the principal (Isaeus 10.24). A second law protected the creditor who acquired a security against any claims made by the

${ }^{40}$ HANSEN (1983) 48. Hansen, however, thinks the clash occurs as a result of «a gap between the constitution and the way it works». I would view the debate between the competing definitions as another example of the open texture of Athenian law.

${ }^{41}$ On these laws see HARRIS (1993) 92-95. 
debtor and his heirs (Dem. 41.7-10). A third law provided the lender with an action against the borrower if he defaulted and refused to turn over goods pledged as security (Isaeus 6.31; [Demosthenes] 56.3, 38, 40, 45). But when did the creditor have the right to seize the security? Did he have to wait until the debtor failed to repay the principal? Or could he distrain after the debtor missed an interest payment?

That depended on the way one interpreted the relationship between the creditor and the debtor in regard to the security during the life of the loan. In a loan agreement the security is pledged to ensure repayment of the principal, not the payment of interest. In favor of this view of the arrangement is the fact that the value of the security was set in relationship to the amount of the loan, not the amount of interest to be paid ${ }^{42}$. And when a creditor distrained on a security, it was not to recover interest that was owed to him, but the principal. For instance, when the merchant Parmeno borrowed forty mnai on the security of his ship and failed to repay the loan, his creditors threatened to seize his ship to recover the principal (Dem. 33.6). After Parmeno repaid these creditors by borrowing from two other lenders, the new creditors drew up an agreement which transferred ownership of Parmeno's ship and slaves until the principal of the loan was repaid (Dem. 33.8).

But there was another way of viewing the relationship between the lender and his creditors in regard to the security. When Nicobulus and Evergus made a loan of one hundred and five mnai to the borrower Pantaenetus on the security of thirty slaves and a workshop in the mining district of Maroneia, they called the resulting arrangement between the parties a «lease with a release at a fixed time» (Dem. 37.4$6)^{43}$. They viewed the pledge of security as a sale which made them the owners of the slaves and workshop. Since they were the owners, the borrower Pantaenetus was therefore in a position similar to that of a lessee. Like the lessee who made regular payments of rent for use of the property, the lender made regular payments of interest for the loan. This view of the relationship brought one significant advantage for the creditors. If one took the standard view that security in a loan was pledged to assure repayment of the principal, a creditor would not be permitted to seize the security until the borrower failed to repay the principal at some fixed date. But in a lease the lessee who does not make a payment of rent must leave the leased property immediately, a principle which was well recognized in Athenian law ${ }^{44}$. Thus if a loan on security was like a lease, the security like a leased property, and the borrower like a lessee, the borrower would have to vacate the property pledged as security as soon as he missed a payment of interest.

These different views of the arrangement led to a dispute between the creditor Evergus and his borrower Pantaenetus. Soon after the agreement (mentioned above) which Evergus and Nicobulus drew up with Pantaenetus was concluded, Nicobulus

\footnotetext{
${ }^{42}$ For securities worth twice the amount of the loan see [Dem.] 34.6; 35.18; Dem. 37.4, 31.

${ }^{43}$ For an analysis of their view of the agreement see HARRIS (1988) 371-72.

${ }^{44}$ See $I G$ ii $^{2} 2496$, lines 17-20; 2499, lines 30-33; 2501, lines 15-20.
} 
set off on a voyage to Pontus while Evergus remained in Athens. Sometime later Nicobulus returned to discover that trouble had erupted during his absence. Not surprisingly there were two versions of what had taken place. Pantaenetus claimed that Evergus had used force to eject him from the workshop contrary to the terms of the agreement. Prevented from carrying on his business, Pantaenetus was unable to make payments on the mine he had leased from the state and became a public debtor (Demosthenes 37.6). Evergus' account was somewhat different. He assured Nicobulus that he had seized the workshop only after Pantaenetus had failed to make several interest payments and denied the accusation that he had used force when taking over the workshop (Demosthenes 37.7). The trouble did not end there. After Evergus took possession, Pantaenetus went away and returned with another set of creditors who said the workshop had also been hypothecated to them. We should not be sceptical about the existence of this other loan; although Mnesicles derided the claims of the other creditors, Nicobulus and Evergus dealt with them in the subsequent negotiations as if their declaration was trustworthy $(13-5)^{45}$.

Even if we accept Evergus' version of what happened, it is clear that he and Pantaenetus had different views about the legal implications of their contract. Evergus considered himself in the position of a lessor, who was entitled to evict his lessee Pantaenetus once the latter missed a few payments. Pantaenetus did not share his view of the matter; he obviously considered himself the owner of the security, which entitled him to pledge his workshop and slaves as security for another loan from a second set of creditors (Dem. 37.13-5) ${ }^{46}$. Since Evergus was not the owner and thus not in a position comparable to that of a lessor, Pantaenetus therefore did not think the Evergus had the right to evict him from the workshop after he fell behind in his payment of interest. He may not have been kept up with his payments, but the date for repayment of the principal had not arrived ${ }^{47}$. Until he failed to repay the principal, he believed that Evergus could not take over the security and claim the workshop as his own.

When the dispute came to trial, the court sided with Evergus and awarded him a payment of damages (Dem. 37.8) His partner Nicobulus claims that Evergus was the victim of malicious suit, but even if we accept Nicobulus' version of events, the court had good reason to decide in Pantaenetus' favor. By voting for Pantaenetus, the court decided to follow the more straighforward interpretation of the agreement between the creditor and the borrower about the security. Since the security was pledged to ensure repayment of the loan, Evergus should have waited to take over the workshop until Pantaenetus defaulted on the principal. By deciding against

\footnotetext{
${ }^{45}$ For the negotiations with these other creditors see HARRIS (1988) 372-76.

${ }^{46}$ For the problem of the ownership of real security and the different views of creditors and borrowers see HARRIs (1988) 361-70.

${ }^{47}$ It is no accident that when describing the agreement, Nicobulus does not specify the due date for repayment of the principal (Dem. 37.5).
} 
Evergus, the court rejected his view of the loan on security as a lease, a less straightforward interpretation of the agreement ${ }^{48}$.

Although the Athenians had laws about real security, these laws did not clear up all questions about the subject. In particular, they did not answer the question who was the actual owner of the security during the life of the loan. As a result, creditors and borrowers might interpret their rights in different ways. In this case, however, the court, when confronted with two differing views of an agreement, sided with the litigant who based his arguments on a more straightforward understanding of the agreement. This fits the pattern I noted in my previous essay: although litigants might attempt to stretch the meaning of the law and although magistrates appear to have often accepted cases based on new or unusual interpretations of a statute or formal agreement, the courts in general preferred to vote for the litigant who adhered to the most common reading of the statute or agreement.

The Athenians had one main law concerning military discipline, which punished various forms of cowardice (deilia). The law contained several provisions, each of which dealt with a specific offense under the general rubric of "cowardice" 49 . In this way it was similar to the law on eisangelia, which enumerated several kinds of crime under the general heading of treason (prodosia). Two offenses included in the law on cowardice were "leaving one's position" (lipotaxion) and desertion or "leaving the army" (lipostration) ${ }^{50}$. In regard to the first offense the law provided for a public action in the case where "someone leaves his position (and goes) to the rear because of cowardice when others are fighting» (Lys. 14.5) $)^{51}$. This provision needs to be understood in the context of hoplite tactics. Before battle, every hoplite was assigned a position in line by his commanding officer (Plato Ap. 28e; Dem. 15.32). It was absolutely necessary that a hoplite remain in his position: the strength of the formation depended on strict discipline and required that each soldier stand in place next to his comrade in the line so as to present a continuous line of shields to the enemy. In fact, every year each ephebe swore in his oath of loyalty that «I will not leave my companion in line in whatever place I will be stationed $»^{52}$. If the tine broke, the enemy would be able to attack from the side and the rear. One should also bear in mind that the hopite shield was only large enough to cover the soldier's left side. He therefore relied on the man to his right to keep his shield in

\footnotetext{
${ }^{48}$ The court may have also favored an interpretation of the agreement that tended to favor the borrower because the average Athenian who was a member of the court was more likely to be a borrower than a lender. Nicobulus in fact alludes to the hostility toward lenders and claims that he is not typical of this group (Demosthenes 37.52-5).

${ }^{49}$ Note how Aeschines (3.175) mentions several types of offenses, then states that one can prosecute them all with the graphe deilias. Cf. Ar. Ach. 1129; Eq. 368.

${ }^{50}$ Note Lys. 14.6 ("the law is established for both offenses").

${ }^{51}$ The speaker then paraphrases this part of the law in the following section where he says it applies to all those who "move toward the back when there is a battle".

${ }^{52}$ For the Ephebic Oath see ToD, Greek Historical Inscriptions 204.
} 
place to protect his unprotected side (Th. 5.71; Eur. Her. 190-94). The part of the law covering this offense is carefully worded and pays careful attention to three substantive issues. First, it only applies to conduct during battle when the duty of maintaining one's position was crucial. Second, it only punishes those who retreat; there was no reason to punish a man for moving forward since this would have brought man closer to the enemy, not farther away. Although the best thing to do was to remain in place, the Greeks did not find worth punishing someone for moving forward. For instance, Herodotus (9.71.2-3) says that in his opinion Aristodemus was the best soldier who fought on Greek side at Plataea even though he left his position. During a meeting shortly after the battle, however, the Spartans agreed that Aristodemus fought well but was not as distinguished as several other soldiers. Their reason was that Aristodemus acted like a madman and rushed forward leaving his position. This shows that it was not considered cowardly to leave one's post provided that one did so to advance toward the enemy, but the man who did so was not as good a soldier as the man who stayed at his post. Third, the law punishes only those who retreat for reasons of cowardice. This leaves open the possibility that a soldier might move back for other reasons such as to change formation under orders or to assist a weak position under attack. One might try to interpret the notion of a soldier's taxis or "post" more broadly, but the wording of the law indicates that the law took it in a narrower sense ${ }^{53}$. The second main offense was astrateia and the law shows that this was failure to show up for duty when summoned and to serve on campaign (Lys. 14.6-7) ${ }^{54}$. Other offenses covered by the law were desertion from the fleet (anaumachiou) and throwing away one's shield ${ }^{55}$.

In around 395, an Athenian named Archestratides brought a charge of "cowardice" against Alcibiades, the son of the famous general of the same name ${ }^{56}$. The speech of Archestratides has not survived but the corpus Lysiacum preserves two speeches delivered by speakers (synegoroi) who supported the accuser. Although the speeches of Alcibiades and his supporters have not been preserved, it is possible to recover the main basic facts of the case, on which both sides implicitly agree. First, neither of the speakers who supported the accuser claim that Alcibiades did not join the expedition or that he left it before its return to Athens. The first speaker says that Alcibiades was enrolled in the infantry, but chose to serve in the cavalry (Lys. $14.7-8,11)$. The second speaker agrees with the first, but is slightly more precise:

\footnotetext{
${ }^{53}$ For instance, Lycurgus (Leocr. 77) accused a man who had left Athens during the crisis after the defeat at Chaeronea of deserting his post. Cf. Aeschin. 3.159.

${ }^{54}$ For astrateia as failure to go on campaign see [Dem.] 59.27; Dem. 39.16. In the next section, however, the charge is given as lipotaxiou.

55 Andoc. 1.74. For desertion from the fleet see also Suidas s.v. anaumachiou.

${ }^{56}$ For the date of the speech see Carey (1989) 141. For the charge see Lys. 14.11, which shows the court will vote whether he is guilty of cowardice. The court appears to have included only those who had served in the army (Lysias 14.5, 14-5), but they are bound by the terms of the judicial oath just like other judges (Lys. 14.40). Cf. BerTRAND (2001) 17-18.
} 
he states that the generals placed Alcibiades in the mounted archers although he was initially assigned to the infantry (Lys. 15.6,11). What is also striking is that neither speaker accuises Alcibiades of deserting his post in battle. When the first speaker notes that their opponents will draw attention to the fact that the army did not fight a battle, he does not contradict them, but argues that the law applies anyway (Lys. 14.5) So much is clear: Alcibiades was enrolled in the infantry, departed with the army, and was transferred to the mounted archers. Thus Alcibiades did not leave the army, and the army never fought a battle during its campaign ${ }^{57}$.

The accusers claim that Alcibiades has violated the law in three ways (Lys. 14.6$7)^{58}$. First, he is guilty of desertion (astrateia) because he did not serve on the campaign as a hoplite although he had been enrolled as one (cf. Lys. 15.11). Second, he is guilty of leaving his post (lipotaxion) because he did not allow himself to be assigned a position in the army (i.e. he transferred to the mounted archers). Third, he is guilty of cowardice in general since he chose to serve in the cavalry and not share the danger of serving as a hoplite. For the first charge, the accusers are narrowing the term "army" (stratia) in the second provision of the law to include only the infantry, not the entire expedition as a whole, both cavalry and infantry. By leaving the hoplites or army on foot, they argue, he has left the army. As Carey has noted, "Only by a linguistic trick can the relevant clause of the law, which by peze stratia ['foot army'] meant the land army as distinct from the fleet, be stretched to fit his conduct" 59 . For the second charge, the accusers are clearly stretching the term taxis to apply to a broader range of actions than those explicitly covered in the statute. The law covers only those who leave their post and move back because of cowardice. The accusers concentrate on the term taxis or assigned place and generalize from it: they claim that anyone who leaves the position assigned to him by law is guilty of deserting one's post (lipotaxion). But Alcibiades took the position in the mounted archers which was assigned to him and did not leave his position during battle nor move to the rear during battle out of cowardice.

The first speaker admits that he is interpreting the law in a new and unusual way when he urges the court to act as lawgivers (Lys. 14.4). He says that the judges should realize that the way they decide the case now will be the way the community applies the law in the future. This implies that in the past the courts had not applied the law to the kinds of offences Alcibiades has committed. If they convict him in this case, they would therefore be expanding the law to cover a wider range of actions than it had before.

${ }^{57}$ If CAREY (1989) 141 is right to identify the Athenian expedition with the one described by Xenophon Hell. 3.5.25, this would confirm the assertion of Alcibiades' supporters.

${ }^{58}$ The two supporting speakers probably summarize the main points against Alcibiades, which were developed in greater detail by Archestratides, who was the actual accuser. On the relationship between supporting speakers and the main accuser in public suits see RUBINSTEIN (2000) 131-47.

${ }^{59}$ CAREY (1989) 145. 
The two speakers give some hints about the arguments their opponents planned to use. First, they would point out that the provision in the law about leaving one's post did not apply since no battle was fought (Lys. 14.5). Even if one applied this provision in the broader way to apply to any position a soldier was assigned to, one could not argue that Alcibiades was disobedient since he had taken the position in the mounted archers assigned to him by the generals (Lys. 15.6.). Significant also is the fact that the generals intended to testify for Alcibiades (Lys. 15.1-4). It is hard to tell who testified for the accusers since all that has survived are the orations delivered by two supporting speakers. But equally significant is the fact that neither speaker attempts to undermine their statements by accusing them of lying. The second speaker claims that the generals in their capacity as magistrates have a duty to remain impartial, but does not attack the veracity of their testimony (Lys. 15.3-4). If Alcibiades had in fact been disobedient, the generals would no doubt have sided with the accuser. To counter their argument, the second speaker claims that they did not have the right to transfer Alcibiades from the infantry to the counted archers, but he cites no law which forbade them to (Lys. 15.6, 12). The second speaker appears to assume that Alcibiades was assigned to a place in the infantry by law, which the generals did not have the right to alter. But it was the magistrates of Athens, who assigned a soldier his post (Dem. 15.32; Pl. Ap. 28e). This makes sense: the laws could not order the generals now to conduct a campaign. If generals could make decisions about how to draw troops up for battle, they must have in the same way been able to move soldiers from one kind of unit to another as the need arose.

The case against Alcibiades relies on a strained reading of the law about cowardice (deilia). Both sides implicitly agree that the army did not fight a battle so the first provision of the law about leaving one's post did not apply. The accusers also do not deny that Alcibiades served on the campaign, did not leave the army, and joined the mounted archers following the orders of his commanding officers so he was not guilty of leaving the expedition. He may have technically violated the provision about serving in the cavalry without passing a scrutiny (Lys. 14.8-9), but we do not know if this law also applied to mounted archers. Besides, there were extenuating circumstances: Alcibiades served in this group at the orders of his commanding officers, not of his own choice.

Although no source reports the court's verdict, it is possible to determine the outcome of the trial. A trial resulting from a charge of cowardice was an agon timetos: the penalty was fixed by statute so there was no assessment of the penalty (timesis) following the court's first vote on the guilt of the defendant (Lys. 14.9) ${ }^{60}$. The penalty was severe: the man convicted of cowardice suffered total disenfranchisement with the complete loss of all rights as a citizen (Dem. 15.32. Cf. [Dem.] 59.27 and Dem. 21.103) ${ }^{61}$. Aeschines (3.179) says that the person guilty of this offense

\footnotetext{
${ }^{60}$ Cf. HARrison (1971) 82.

${ }^{61}$ According to Andoc. 1.74 the person convicted on a charge of cowardice retained his property, but Lys. 14.9 may imply that the penalty included confiscation of property. See CAREY (1989) 155.
} 
was banned from the sacred area of the agora and could not participate in public rituals. If someone no longer qualified as a citizen, his children and grandchildren could not become citizens ${ }^{62}$. But Alcibiades appears to have had a daughter who was a citizen and a grandson, who was also named Alcibiades ${ }^{63}$. This would have been impossible if Alcibiades had been convicted for cowardice and lost his rights as citizen. Since the case against him was very weak, it is not surprising that Alcibiades must have been acquitted ${ }^{64}$.

If this analysis is correct, the case against Alcibiades conforms to the pattern noted in the previous example. On the one hand, the magistrate who received the accusation, presided at the anakrisis, and assigned the case to a court for trial, was willing to accept a case that relied on a novel interpretation of the law. On the other, the court by contrast was unwilling to convict a defendant on charges based on an unusual reading of the law's provisions.

This study should serve as another reminder that the Athenians did not think their laws were concerned primarily with matters of procedure. As I noted in my previous essay on "Open Texture in Athenian Law", one should also not draw the wrong conclusion from the absence of definitions in Athenian statutes. In all the cases we have examined, the litigants pay careful attention to substantive issues and questions about the interpretation of law; they would only have done so if they considered themselves bound to adhere to the letter of the law ${ }^{65}$.

Although the Athenians were aware of the open texture of law, litigants tended to deal with the problems posed by open texture in a way different from that of modern lawyers in Common Law jurisdictions. An Athenian litigant addressed both his arguments about the law and his arguments about the facts to a court made up of his fellow citizens. In a modern jury trial, the jury decides only about the facts; the lawyer directs his arguments about the law to a professional judge. If there is a dispute about the meaning of a law, the modern lawyer in a Common Law system appeals to precedents, which the judge presumably knows, in order to resolve the dispute. Thus modern lawyers and judges do not have to hide the fact that law has open texture since the Common Law provides them with an institutional means of dealing with the issue. This was not true for the Athenian litigant: in Athenian law

\footnotetext{
${ }^{62}$ Ath. Pol. 42.1 with RHodes (1981).

${ }^{63}$ For the daughter see $I G \mathrm{ii}^{2} 7400$; for her husband see $I G \mathrm{ii}^{2} 6746$ with 7400 ; for the grandson see $I G$ ii $^{2}$ 6719. Cf. DAVIES (1971) 21-22.

${ }^{64}$ Cf. CAREY (1989) 145: «the case against Alcibiades is not strong».

${ }^{65} \mathrm{~A}$ careful analysis of the legal arguments in the orations thus refites the assertion made by CHRIST (1998). 195, that the courts did not feel «bound to apply individual laws to the letter». CHRIST further claims that the judges «determined how and whether to enforce laws on the basis of a more fundmental standard - namely, the sense of "what is just" (ta dikaia)». But as CAREY (1996) 41, has noted, the orators generally do not consider law and justice as differing standards, but tend to use the two words as virtual synonyms.
} 
there was no doctrine of binding precedents, no written opinions kept on record, and no professional body of judges who studied these opinions to discover what precedents bound their decisions. As a result, Athenian litigants tended to claim that the meaning of the law was clear and that they relied on the customary understanding of a given statute. By contrast, a modern lawyer can admit that a statute can be interpreted two ways, but argue that his interpretation is supported by precedents. An Athenian litigant would claim that he was following the law and that his opponent was not. But we should not allow this rhetoric to deceive us. As we have seen, several of the disputes that gave rise to litigation in Classical Athens arose from differing interpretations of the law.

Yet despite the absence of definitions to guide their decisions and a doctrine of binding precedent, the Athenian courts showed some concern for applying statutes fairly and consistently by rejecting unusual interpretations of the law. But that is only what we should expect from a community that took the rule of law very seriously.

\section{BIBLIOGRAPHY}

Bertrand, J.-M.: "Platon et les lois sur la discipline militaire", Quaderni del dipartimento di filologia linguistica e tradizione classica Augusto Rostagni (2001) 9-27.

Biscardi, A.: Studi di diritto greco (Milan, 1999).

CARAWAN, E.: Rhetoric and the Law of Draco (Oxford, 1998).

CAREY, C.: Lysias: Selected Speeches (Cambridge, 1989).

— "Nomos in Attic Rhetoric and Oratory", JHS 116 (1996) 33-46.

— "The Shape of Athenian Laws", CQ 48 (1998) 93-109.

CAREy, C. \& ReID, R. A.: Demosthenes: Selected Private Speeches (Cambridge, 1986).

Cartledge, P. A., Millett, P. C. \& von Reden, S.: (eds.) Kosmos: Essays in Order, Conflict and Community in Classical Athens (Cambridge, 1998).

CoHen, D.: Law Violence, and Community in Classical Athens (Cambridge, 1995).

Christ, M. R.: The Litigious Athenian (Baltimore and London, 1998).

Davies, J. K.: Athenian Propertied Families 600-300 B.C. (Oxford, 1971).

GAGARIN, M.: Drakon and Early Athenian Homicide Law (New Haven and London, 1981).

— "Self-Defence in Athenian Homicide Law", GRBS 19 (1978) 111-20.

- Antiphon: The Speeches (Cambridge, 1997).

Gagarin, M. \& MACDowell, D. M.: Antiphon and Andocides (Austin, 1998).

Hansen, M. H.: Eisangelia: The Sovereignty of the People's Court in Athens in the Fourth Century B. C., and the Impeachment of Generals and Politicians (Odense, 1975).

- Apagoge, Endeixis, and Ephegesis against Kakourgoi, Atimoi, and Pheugontes (Odense, 1976).

— "The Athenian Politicians, 403-322", GRBS 24 (1983) 33-55.

HARris, E. M.: "When is a Sale Not a Sale? The Riddle of Athenian Terminology for Real Security Revisited", CQ 38 (1988) 351-81. 
- "Apotimema: Athenian Terminology for Real Security in Leases and Dowry Agreements", CQ 43 (1993) 73-95.

- "Law and Oratory", in Persuasion: Greek Rhetoric in Action, ed. I. Worthington (London and New York, 1994) 130-50.

- (2000a): “Open Texture in Athenian Law", Dike 3 (2000) 27-79.

- (2000b): Review of Christ (1998), CR 50.2 (2000) 499-501.

— "How to Kill in Attic Greek", Symposion 1997: Vorträge zur griechischen und hellenistischen Rechtsgeschichte, ed. E. Cantarella \& G. Thür (Cologne, Weimar, and Vienna, 2001) 75-87.

- (forthcoming). "Feuding or the Rule of Law? The Nature of Litigation in Classical Athens", Symposion (2001).

Harrison, A. R. W.: The Law of Athens: Procedure (Oxford, 1971).

HART, H. L. A.: The Concept of Law (Oxford, 1961).

Hillgruber, M.: Die zehnte Rede des Lysias: Einleitung, Text, und Kommentar mit einem Anhang über die Gesetzinterpretationen bei den attischen Rednern (= Untersuchungen zur antiken Literatur und Geschichte 29) (Berlin, 1988).

KATZ, L.: Bad Acts and Guilty Minds (Chicago, 1987).

Loomis, W. T.: "The Nature of Premeditation in Athenian Homicide Law", JHS 92 (1972) 86-95.

MacDowell, D. M.: Athenian Homicide Law in the Age of the Orators (Manchester, 1963).

- Demosthenes: Against Meidias. Oration 21 (Oxford, 1990).

MeINECKE, J. "Gesetzesinterpretation und Gesetzanwendung im Attischen Zivilprozess", Revue internationale de droit de l'antiquité 18 (1971) 275-360.

Meyer-Laurin, H.: Gesetz und Billigkeit im Attischem Prozeß (Weimar, 1965).

Rhodes, P. J.: A Commentary on the Aristotelian Athenaion Politeia (Oxford, 1981).

RICKERT, G.: HEKŌN and AKŌN in Early Greek Thought (Atlanta, 1989).

RubinsteIn, L. (1998). "The Athenian political perception of the idiotes", in Kosmos: Essays in Order, Conflict and Community in Classical Athens, ed. P. A. Cartledge, P. C. Millett \& S. von Reden (Cambridge, 1998), 125-43.

- Litigation and Cooperation: Supporting Speakers in the Courts of Classical Athens (Stuttgart, 2000).

Stroud, R.: Drakon's Law on Homicide (Berkeley, 1968).

ToD, M. N.: Greek Historical Inscriptions II (Oxford, 1948).

ToDD, S. C.: The Shape of Athenian Law (Oxford, 1993).

Wallace, R. W.: The Areopagos Council to 307 B.C. (Baltimore and London, 1989).

WhiteneAD, D.: Hypereides: The Forensic Speeches. Introduction, Translation and Commentary (Oxford, 2000).

WoLf, E.: Griechisches Rechtsdenken III/2 (Frankfurt, 1956).

WolfF, H. J.: "Verjährung von Ansprüchen nach Attischem Recht", in Eranion für Maridakis (Athens, 1963) 87-109.

Worthington, I. ed.: Persuasion: Greek Rhetoric in Action (London and New York, 1994). 